\title{
LA IGLESIA «DEVASTADA». LA SANTA SEDE Y LOS TERRITORIOS INCORPORADOS A LA ZONA FRANQUISTA DURANTE LA GUERRA CIVIL (1937-1938)*
}

\author{
POR \\ SANTIAGO NAVARRO DE LA FUENTE ${ }^{1}$ \\ Universidad de Sevilla
}

\begin{abstract}
RESUMEN
Durante su misión en España entre julio de 1937 y junio de 1938, monseñor Ildebrando Antoniutti realizó distintas visitas a los territorios que el ejército franquista iba incorporando a su dominio. Las informaciones enviadas a la Santa Sede al respecto constituyen una visión muy completa de la diferente situación de la Iglesia en cada zona del país así como de sus necesidades y potencialidades. A partir de la documentación vaticana que recoge estas informaciones, el presente artículo analiza el diferente punto de partida para la reconstrucción de la Iglesia en cada región y el modo en que la Santa Sede lo abordó.
\end{abstract}

PALABRAS CLAVE: iglesias devastadas; España; Guerra Civil; Antoniutti; diplomacia vaticana.

\section{THE «DEVASTATED» CHURCH. THE HOLY SEE AND THE TERRITORIES CONQUERED BY FRANCO DURING SPANISH CIVIL WAR (1937-1938)}

\begin{abstract}
During his mission in Spain between July 1937 and June 1938, Mons. Ildebrando Antoniutti visited different territories incorporated by the francoist army. The information sent to the Holy See about these visits offered a full vision about the differences in the status of the Church within each area of the country, their needs and possibilities. Based on the information from the Vatican Archive, this paper analyzes the different starting points of the rebuilding of the Church in each region and the way the Holy See faced it.
\end{abstract}

KEY WORDS: devastated churches; Spain, Civil War; Antoniutti; Vatican diplomacy.

Cómo CITAR ESTE ARTículo / CitATION: Navarro de la Fuente, Santiago. 2020. "La Iglesia "devastada". La Santa Sede y los territorios incorporados a la zona franquista durante la Guerra Civil (1937-1938)». Hispania Sacra LXXII, 146: 593-604. https://doi.org/10.3989/hs.2020.044

$\begin{array}{ll}\text { Recibido/Received } & 21-01-2019 \\ \text { Aceptado/Accepted } & 14-11-2019\end{array}$

Entre julio de 1937 y la primavera de 1938 monseñor Ildebrando Antoniutti desarrolló una intensa labor diplomática y asistencial en la España de la Guerra Civil que estaba bajo control de Franco. Hasta entonces Delegado Apostólico en Albania, fue destinado a España con el propósito formal de colaborar en la iniciativa de repatriación de los niños vascos enviados al extranjero en previsión de la caída del

* Proyecto de Investigación «Modernidad y religión en la España del siglo XX: entre el consenso y la ruptura» (PGC2018-099909-B-100) (MCIU/AEI/FEDER-UE)

1 snav@us.es / ORCID iD: https://orcid.org/0000-0002-2706-0770 frente del norte. ${ }^{2}$ También tuvo parte en la decisión del envío la petición del ministro de Exteriores italiano, conde Ciano, para que la Santa Sede enviase un observador que comprometiera a Franco a garantizar el cumplimiento de las condiciones de rendición que los fascistas negociaban con los gudaris vascos, con el fin de evitar una nueva masacre represiva similar a la que los franquistas habían cometido

2 Los estudios específicos sobre el retorno de los niños vascos enviados al exterior han abordado también la dimensión propagandística que el bando sublevado otorgó a la iniciativa (Pazos 2013, 392397; Alonso Carballés 1998, 401). 
en Málaga y que había impresionado incluso a los hombres de Mussolini (Navarro de la Fuente 2019, 326-327). El peso diplomático del obispo italiano justificó que fuese elevado a la condición de Encargado de Negocios ante Franco al poco de su llegada, presentando sus cartas credenciales el 7 de octubre de 1937.

La intensa actividad que desarrolló en España durante su estancia en la zona controlada por Franco le llevó a escribir en sus memorias que durante aquellos meses su casa fue la carretera (Antoniutti 1975, 35). Una de las razones que motivaron sus constantes viajes fue la visita que hubo de efectuar a las zonas que el ejército franquista fue incorporando al territorio bajo su control después de haber permanecido en lealtad formal al Gobierno de la República desde el inicio de la guerra. Se ocupó especialmente de conocer y atender la situación en que la Iglesia había quedado en aquellos territorios, expuestos desde el inicio del conflicto a la "saña antirreligiosa» de las milicias. La documentación generada a partir de estas visitas quedó depositada en una carpetilla que destinó a los territorios que consideró «liberados», es decir, que pasaban de manos de las milicias que defendían la República a las de la "España nacional». ${ }^{3}$ Estas visitas permitieron a Antoniutti conocer las distintas realidades en que se insertaba la Iglesia, con características singulares en cada uno de los territorios que fue visitando a medida que se iba desplazando la línea del frente. La información que el Encargado de Negocios ante Franco remitió a la Santa Sede a partir de ellas constituye una valiosa geografía eclesiástica que alude a las carencias, los retos y las virtualidades de la Iglesia que se enfrentaba a la labor de su propia reconstrucción. Estas noticias han sido poco estudiadas en contraste con el general conocimiento de la misión del eclesiástico en España durante la guerra. Con todo, la labor de Antoniutti no fue solo la de informar sobre la situación en la que se encontraban las iglesias que llamó «devastadas", sino también la de socorrer en nombre de Pío XI las necesidades de la población y de la Iglesia en aquellas regiones (Robles 2009 y Martínez Sánchez 2007). Se convirtió así no solo en informador sobre estas situaciones, sino en un agente fundamental de los primeros tiempos de la restauración católica de aquellas diócesis. ${ }^{4}$

\section{LA VISITA A LAS IGLESIAS DEVASTADAS}

Después de su accidentada entrada en España, habiéndosele retenido durante algunas horas en la frontera con Francia (Cárcel 2008, 308), el primero de los viajes que Antoniutti realizó en España fue el que le llevó desde Pamplona, donde se instaló en la noche del 26 de julio de 1937 a su llegada, hasta Salamanca, que visitó junto con

3 Abreviaturas utilizadas: ASV $=$ Archivio Segreto Vaticano; AES = Archivo de la Sagrada Congregación de Asuntos Eclesiásticos Extraordinarios. La carpetilla en ASV, Nunziatura di Madrid, b. 969, ff. 474-516. Al respecto pueden encontrarse también otras informaciones, especialmente recortes de periódicos sobre la persecución religiosa y - particularmente- sobre los mártires de Barbastro en ASV, Nunziatura di Madrid, b. 977, ff. 237-259.

4 Al final de su misión, Antoniutti envió a la Secretaría de Estado vaticana un balance de su gestión económica que ha permitido una reconstrucción tanto del destino de los donativos del representante del Papa como de su procedencia (Navarro de la Fuente 2019, 513-525). el cardenal primado Isidro Gomá y donde se encontró con el general Franco. En sus memorias, recordaba haber efectuado aquel primer viaje en compañía del abad de Monserrat, Antoni Maria Marcet. Este se había refugiado en Navarra de la persecución desatada en Cataluña. A través de su testimonio, Antoniutti conoció la situación que había atravesado el monasterio. Supo por él de los «horrores y masacres» de que habían sido víctima varios de sus monjes, mientras otros habían huido para escapar de la muerte (Albareda 1972, 107-108). En cuanto al edificio, había sido adaptado a usos profanos convirtiéndose en residencia del Presidente de la República y albergando la celebración de algunas sesiones de Cortes y otras reuniones «de carácter revolucionario» (Antoniutti 1975, 35-36).

\section{Vizcaya}

Antoniutti se encontró con el cardenal Gomá en Valladolid y este le llevó a un discreto primer encuentro con Franco que tuvo lugar en Salamanca el 31 de julio. Ambos le recomendaron instalarse lejos del País Vasco, pero su misión estaba precisamente en aquella región por lo que la Santa Sede le instó a que hiciese comprender a Franco que había de establecerse en Euskadi. Durante el trayecto que le llevó desde Salamanca hasta el País Vasco, el todavía Delegado Apostólico en Albania aprovechó para visitar la región y tomar algunos datos con los que informar de primera mano a la Santa Sede. Destacó entonces la tranquilidad que notaba en aquellos parajes, en los que encontró incluso una «cierta abundancia». Pero mientras que recibía el calor popular de algunas gentes que le recibían con vivas al Papa y a Cristo Rey, también tuvo ocasión en aquellas primeras jornadas de constatar cómo la división política había afectado a las estructuras eclesiales. En su camino hacia Bilbao, se detuvo a visitar a la comunidad de pasionistas de Villanañe (Álava), que encontró muy dividida entre los religiosos partidarios de los nacionalistas vascos y los que defendían la causa de Franco (Navarro de la Fuente 2018). Con todo, la destrucción de iglesias y la persecución del clero fue mucho más moderada en la zona controlada por los gudaris vascos que en el resto del territorio republicano, aunque se ha puesto de manifiesto que este "oasis" lo fue solo de modo muy relativo (Pablo Contreras, Goñi Galarraga y López Maturana 2013, 337-339). En cualquier caso, la visita había de servir para aumentar las reservas que Antoniutti empezaba a mantener respecto de los nacionalistas vascos, de cuya postura política le habían prevenido las informaciones aportadas por la Secretaría de Estado vaticana, en las que consideraban "vergonzoso» el sostenimiento de la lucha en coalición con las izquierdas revolucionarias. ${ }^{5}$

El 5 de agosto Antoniutti estuvo en Vitoria, donde se celebraba ese día la festividad de la patrona de la ciudad, la Virgen Blanca. La fiesta supuso toda una muestra de fervor popular del que quedó gratamente impresionado (Antoniutti 1975, 36). Tres días después de aquella celebración preparó un pequeño informe sobre su visita a la Iglesia en los territorios que habían sido «liberados». Fue el primero del conjunto de informaciones que iría enviando sobre su percepción del estado religioso en las regiones que

\footnotetext{
5 Navarro de la Fuente 2019, 329.
} 
pasaban a control de los franquistas. La continua actividad de los frentes habría de llevarle a ocuparse de la preparación de estos informes a lo largo de toda su estancia en España. Este primero de ellos, fechado el 8 de agosto de 1937, contenía sus impresiones recibidas durante la visita al entorno de Durango (Vizcaya) antes de su llegada a Bilbao. La villa había sido bombardeada el 31 de marzo por la aviación italiana, pero Antoniutti no reparó en ello. ${ }^{6}$ Indicó que había visitado algunas poblaciones cercanas donde las iglesias habían sido dañadas "por los rojos», que habían demolido los altares, destrozado las imágenes sagradas e incendiado los objetos de culto. La destrucción de iglesias estaba llamada a ser punto común de los informes sobre las visitas que estaba por realizar puesto que afectaba a todo el territorio gubernamental; de forma que Antoniutti llegó a recibir incluso recomendaciones de arquitectos para los trabajos de reconstrucción. ${ }^{7}$ Los ataques habidos durante el periodo previo a la conquista de las tropas franquistas contrastaban -en las letras que envió a Roma-con el entusiasmo de la población que le había recibido. Al enviado de Pío XI le llamó la atención que las gentes, al enterarse de su paso, improvisaran afectuosas manifestaciones de devoción y profiriesen vivas al Papa, a Cristo Rey y a España. ${ }^{8}$

La comunicación de Antoniutti con Roma no tenía solo un interés informativo, sino que también tuvo como objetivo pedir ayuda para aquellas iglesias destruidas que tanto le habían impresionado por estar en penosas condiciones. A pesar de que ya se habían enviado desde diversas zonas de la «España nacional» imágenes y objetos de culto, ${ }^{9}$ las necesidades continuaban siendo muy superiores a los envíos. En especial pedía a Roma algo tan esencial como delicado de producir y transferir: cálices y misales. A juzgar por la documentación conservada en el fondo de la Nunciatura de Madrid, él mismo se comprometió en la reconstrucción de algunas de aquellas iglesias, como en el caso de la de Santa María de Uribarri en Durango (Vizcaya), para la que se le requirió ayuda y a la que destinó cinco mil pesetas. ${ }^{10}$

\section{Santander}

El avance del frente norte y la incorporación de Santander a la zona controlada por Franco marcó la siguiente etapa del

\footnotetext{
6 Una referencia al bombardeo de Durango, con amplio material gráfico, en Irazabal Agirre 2001.

7 Es el caso de la recomendación que el cónsul de Italia, Cavalletti, hizo del arquitecto Giovanni Battista Cassaghi mediante carta de 19 de abril de 1938. En ASV, Nunziatura di Madrid, b. 969, f. 346. En Archivo de la Embajada Española ante la Santa Sede, Serie 1901-1948, legajo 50, aunque para el mes de octubre de 1938 en que había terminado la misión de Antoniutti, también puede encontrarse documentación relativa a las propuestas de varios arquitectos y constructores para lo que parecía un negocio importantísimo: la reconstrucción de las iglesias en España.

8 La copia del informe en ASV, Nunziatura di Madrid, b. 969, f. 477.

9 En enero de 1937 la Comisión de Cultura y Enseñanza había dispuesto el envío de objetos de culto que sobraran en las iglesias a aquellas que habían sido atacadas. El arzobispo primado no se había mostrado demasiado satisfecho con esta iniciativa legislativa sobre bienes que eran de Iglesia, y así lo indicó a la Secretaría mediante escrito de abril de 1937 en AES, Spagna (IV), pos. 901, fasc. 306, f. 54.

10 Así consta anotado a mano en el margen de la petición de ayuda. ASV, Nunziatura di Madrid, b. 974, ff. 194-196.
}

recorrido del enviado del Papa. En los recuerdos que de ello conservó al final de su vida estaba la impresión del desastre provocado en la catedral, donde se habían almacenado gran cantidad de objetos sagrados robados de las iglesias de la diócesis. Recordaba también su encuentro con algunos fieles que "lloraban de alegría» al sentirse libres para cumplir sus obligaciones religiosas, un gozo que se alternaba con la consternación provocada por la multitud de ciudadanos que habían sido asesinados arrojándolos al mar. Fue el destino que tuvieron los monjes trapenses de Cóbreces, cuyo «sacrificio» impresionó al viajero (Antoniutti 1975, 36; Montero Moreno 2000, 349-352).

Los recuerdos que Antoniutti conservaba al escribir sus breves memorias complementan la información que en aquellos días envió a la Secretaría de Estado vaticana a partir de su visita a la Cantabria que cambiaba de lado en la guerra. La primera redacción del informe sobre Santander fue escrita el 3 de septiembre de 1937, cuando aún se prolongaba su estancia en la ciudad que había iniciado el primer día del mes (Robles 2009, 731), apenas cinco después de la entrada de las tropas de Franco en la ciudad cántabra; sin embargo, la redacción final no se envió hasta el día 7 de septiembre. Entre las diferencias de ambas redacciones merece la pena destacarse la que se refería al número de vascos huidos de Santander, que inicialmente era de sesenta mil y en la segunda redacción se elevaba hasta ochenta mil. A diferencia de lo que luego hizo constar en sus memorias, el enviado pontificio destacó los daños relativamente leves sufridos por la ciudad a causa del rápido avance de los «nacionales», que impidió en buena medida los deterioros de la refriega y la táctica de tierra quemada. La ciudad cayó sin resistencia, pero presentaba un desolador aspecto de pobreza y suciedad. Los "comunistas» habían destruido un barrio señorial para construir la avenida de Rusia, edificando solo refugios antiaéreos que terminaron por ser usados como sede de interrogatorios y juicios. No guardaba para sí las impresiones - ya parciales - que le había provocado la visita, de forma que hablaba de sensación de alivio entre los habitantes de la ciudad entonces "liberada», recuerdo que mantuvo hasta el momento de escribir su propia semblanza. ${ }^{11}$

Al tratar de los desplazados que habían huido a Santander después de la caída de Bilbao, presentó a los "comunistas» como los responsables de esa movilización, diciendo que "obligaron» a la gente a seguirles. ${ }^{12}$ Como consecuencia de ello, los huidos habían pasado los meses al raso tanto en la ciudad como en el entorno, con medios «limitadísimos» de vida. Vencida Santander, los refugiados volvían a sus casas transformados por la penuria. Antoniutti daba cuenta de sus conversaciones con ellos (Botti 2007, 472-473) y advertía a la Secretaría de Estado que se quejaban, sobre todo, de que los dirigentes católicos y los sacerdotes vascos «hubieran sido la causa de tanto sufrimiento y tantas privaciones para

11 El informe original sobre la visita en AES, Spagna (IV), p.o. 907, fasc. 314, ff. 26-29. La copia en ASV, Nunziatura di Madrid, b. 969, ff. 478-479.

12 Durante la batalla del norte, la Santa Sede pidió al cardenal Gomá que interviniese para minimizar los daños de la guerra. Entre la caída de Bilbao y la de Santander se redoblaron los esfuerzos para lograr la rendición de los gudaris vascos ante las tropas italianas (Dionisio Vivas 2015, 195). 
sostener una lucha loca de acuerdo con los enemigos de la religión y de la patria». Era — decía- «la tragedia de esta pobre gente».

El informe continuaba explicando las prácticas de represión de los "comunistas» y el uso en ellas de un faro de cincuenta metros de altura sobre el mar, al que se habían arrojado muchos cuerpos que incluso llegaron a aparecer en la costa francesa..$^{13}$ Los sacerdotes prisioneros también habían contado las torturas sufridas al enviado del Papa. En cuanto a las iglesias, todas habían sido profanadas y destinadas a usos de guerra; aunque muchas podrían reabrirse pronto. De hecho, advirtió a la Secretaría de Estado que los "comunistas» habían comenzado a respetar los edificios religiosos, conservándolos para otros usos. Las imágenes habían sido mutiladas, como la estatua del Sagrado Corazón próxima a la iglesia de los jesuitas que estaba decapitada. Muchos objetos de culto habían sido robados y en la iglesia de la Compañía de Jesús se había instalado un horno para extraer el metal de los objetos preciosos robados a las iglesias. Sin embargo, la urgencia de los "comunistas» en la huida permitió recuperar de él objetos de valor para el culto: cálices, candeleros, lampadarios... incluso algunos ornamentos.

El culto había sido suprimido y los sacerdotes perseguidos y asesinados en su mayoría. De entre los diocesanos calculaba Antoniutti la muerte de unos ochenta; ${ }^{14}$ pero puntualizaba que en Santander se encontraban muchísimos más de otras diócesis que realizaban sus ejercicios espirituales en Comillas, edificio que - pese a haberlo previsto- no fue incendiado por los «rojos» y que aprovechó para visitar junto con el obispo de la diócesis. El Delegado Apostólico se afanó en obtener del Papa los donativos necesarios para la puesta a punto del seminario y la inauguración del curso para finales de 1937, haciendo de él refugio para los seminaristas de diócesis limítrofes y de algunos otros huidos de Cataluña (Antoniutti 1975, 36-37 y Navarro de la Fuente 2019, 514). También en el recorrido de Santander a Comillas recibió el homenaje afectuoso del pueblo sencillo, en forma de vivas y aplausos.

Con el dinero destinado al efecto por Pío XI, Antoniutti dispuso la asistencia a los niños de los refugiados. Otras cincuenta mil pesetas fueron entregadas al obispo para la obra de asistencia a los niños pobres, quien telegrafió al Santo Padre mostrando su gratitud como también se la mostraron al enviado del Papa las autoridades.

La posición de la Iglesia en el delicado momento en que el territorio de la diócesis montañesa pasaba de un lado a otro de la línea del frente puede bien seguirse a partir de las orientaciones que el obispo, Eguino y Trecu, dirigió a su clero para el momento en que los sacerdotes hubieran de reincorporarse en sus parroquias. En el fondo archivístico de la Nunciatura se conserva copia de esta circular, fechada el 31 de julio de 1937 desde Burgos y estandarizada en un folio impreso a doble cara y con el espacio para señalar el nombre de la parroquia a la que habría de dirigirse cada una de las copias. El texto se iniciaba preparando al sacerdote

13 Fue este el final de los monjes trapenses de Cóbreces citados arriba (Montero Moreno 2000, 349-352).

14 Montero Moreno $(2000,764)$ los cifró en 77 sacerdotes asesinados respecto de los 505 que integraban el clero diocesano, un 15,2 \% del total. receptor a la situación de extrema desolación a que había de enfrentarse:

Prepárese al llanto y al dolor [...] tendremos que llorar nosotros sobre nuestras iglesias derruidas, sobre los altares rotos y las imágenes mutiladas... Y si el Ilanto que estas ruinas materiales ha de causarnos ha de ser muy grande, témome que no ha de ser menor el que nos causen sus ruinas espirituales. ${ }^{15}$

Añadía entonces la preocupación sobre el efecto que el año de «dominio rojo» habría podido causar en la perseverancia en la fe de los fieles. Advertía que quizás su imaginación, llevada por el temor de ver aniquilada la diócesis, estuviera exagerando los males y que la realidad no alcanzara a ser tan dramática. En cualquier caso, no planteaba aquella perspectiva más que para urgir ante ella a imitar el celo apostólico de los primeros discípulos y a hacer de su presbiterio una fuerza al servicio de la paz y de la reconciliación:

Con el pax vobis del Salvador en los labios y con el corazón rebosante de caridad, vamos a entrar en el pueblo. Avancemos sembrando el bien y exterminando toda discordia, y como el esplendor del sol ilumina el cielo, así nuestra parroquia se iluminará con las dulces claridades de la paz.

Las palabras tenían especial resonancia en un momento que se había de caracterizar por la inmediata represión de las fuerzas conquistadoras sobre la población que había de acatar a las nuevas autoridades; una represión que prometía mostrarse implacable contra quienes pudieran haber sido tenidos por colaboradores de «los rojos». Sin embargo, esta voluntad del prelado se mostraba todavía más clara al comenzar la parte dispositiva del texto: doce puntos con mandatos concretos sobre la actitud del clero una vez retornado a sus ministerios. De ellos, el primero era el más peculiar, puesto que dejaba el momento concreto del retorno del sacerdote a su parroquia a la prudencia de cada caso. Esto es, recomendándose que se posesionaran de las parroquias a la mayor brevedad, indicaba veladamente que se evitara hacer aparecer al párroco como un colaborador de las fuerzas represivas en el momento de la conquista, dejando la asistencia espiritual en ese primer tiempo en manos de los capellanes castrenses, si era preciso:

Respecto al momento en que los Sres. Párrocos o Ecónomos deben hacerse cargo de sus parroquias, no es posible dar un mandato concreto e igual para todos, por ser muy distintas las circunstancias en que los mismos se encuentran. Sería de desear que desde el primer instante de la liberación tuviesen consigo los pueblos a su Sr. Cura; pero no siendo esto siempre posible ni tal vez prudente, por razones que a nadie se le ocultan, se deberá examinar cada uno de los casos en particular. Estén, pues, los sacerdotes a la mira, viendo cómo se desenvuelven los acontecimientos en sus respectivos pueblos y, puesta esta diligencia, cada uno podrá apreciar, bajo la responsabilidad de su conciencia, cuándo es llegada la hora oportuna para entrar en la parroquia y empezar de nuevo a trabajar en ella. - A fin de que desde los primeros momentos estén atendidos los

15 Una copia del mismo en ASV, Nunziatura di Madrid, b. 970, f. 193 rvto. 
fieles, los Capellanes Castrenses que acompañan a las tropas liberatrices [sic], se encargarán de realizar entre ellos toda la labor espiritual posible, en conformidad con las instrucciones del Excmo. Sr. Obispo Pro-Vicario Castrense. ${ }^{16}$

La entrada del sacerdote en la parroquia debía hacerse con la mayor sencillez, y al punto debía comenzarse a trabajar en favor de todas las almas, evitando las discordias:

Trate desde el principio de atender a todas y cada una de las ovejas de su grey, fortificando a las débiles, curando a las enfermas, consolando a las tristes, atrayendo a las que huyen, buscando a las perdidas. Sean sus palabras evangelium pacis y predique y catequice $a$ todos, in omni patientia.

Las siguientes medidas eran, por lo general, mucho más canónicas. Se disponía que los sacerdotes retomaran el traje talar lo antes posible, evitando continuar vistiendo como seglares tal y como habían hecho por prudencia durante la «persecución». En cualquier caso, si el presbítero había de vestir como seglar hasta que pudiera adquirir un nuevo traje talar, se le indicaba expresamente que lo hiciera con la mayor dignidad y «evitando todo lo que signifique partidismo». Indicación especialmente oportuna para contrarrestar el triunfalismo que pudiera darse en algunos. Tras otras indicaciones más sobre el oficio divino y sobre el mantenimiento de la plegaria por la paz en la celebración de la misa, se notificaba la prórroga de las licencias ministeriales hasta que pudiera normalizarse su renovación. Se disponía también la nueva consagración de las iglesias, altares y cementerios que hubieran sido profanados. En aquellos casos en los que no se tuviera la certeza de que así hubiera sido, el obispo recomendaba proceder de igual manera por cautela. En caso de falta de altar, se permitía provisionalmente la celebración de la misa sobre una mesa cubierta con paños blancos. Las prescripciones no dejaban de ser indicativas de la situación:

Cuando por haber sido destruido el altar, no es posible celebrar la Santa Misa sobre el Ara consagrada, celébrese sobre una mesa cubierta con paños blancos. El celo por el decoro de la Casa de Dios, en el que arden nuestros sacerdotes, ideará medios para adornar decorosamente con cuadros o imágenes los improvisados altares, en los que nunca ha de faltar la imagen de Jesucristo Crucificado. - Para los primeros días, en los que no es posible tener Cáliz, se supone vigente el privilegio concedido por la Santa Sede a los sacerdotes españoles perseguidos, de poder consagrar en un vaso de cristal. No autorizamos, sin embargo, para poder celebrar con traje seglar, sin ornamentos sagrados tan sólo se concede el uso de color distinto del rito, a falta del propio. Para evitar el escándalo de los fieles, notifíquese en la iglesia la existencia del privilegio. - Por medio de comisiones nombradas al efecto, se procurará que todas las parroquias tengan, lo más pronto posible, ornamentos, vasos sagrados y demás objetos necesarios para la digna celebración del culto.

Por último, y después de disponer que se ubicase en cada iglesia un sagrario y un confesonario, llamaba especialmente la atención el cuidado con el que el obispo se

\footnotetext{
16 El término en cursiva aparece así en el original.
}

preocupaba de que los niños que no lo habían sido fueran bautizados a la mayor brevedad: "Si en la parroquia hay niños sin bautizar y se pide su bautismo, téngase en cuenta que es preferible administrarlo inmediatamente, con la materia y forma necesarias, dejando para ocasión oportuna el suplir las demás ceremonias del ritual». Para los casos relativos a los matrimonios, uniones civiles, legitimaciones y análogos, Eguino y Trecu pedía a los sacerdotes que se dirigiesen al Vicario General para que pudiese resolver lo oportuno en cada caso.

\section{Asturias}

En la última semana de noviembre de 1937 tuvo lugar la visita de Antoniutti a Asturias, que había sido completamente conquistada poco tiempo antes por el que llamó "ejército nacional», haciendo uso de la terminología propia del «nuevo Estado». En su informe a la Secretaría de Estado, de 6 de diciembre de aquel año, ${ }^{17}$ el enviado pontificio indicaba que había visitado una cincuentena de poblaciones, con especial atención a Oviedo, Gijón y Covadonga. En aquella ocasión, el informe dejaba mayor riqueza de matices que sus análogos precedentes, dibujando una completa sensación de desolación que se alejaba de la casi amable descripción que se había hecho de Santander. Oviedo fue presentada, por el contrario, como el exponente máximo de la decrepitud, en medio de la que se decía que restaban intactas tan solo dieciséis casas. Explicó Antoniutti que la ciudad, más que ninguna otra, estaba marcada por los signos de la lucha. Sublevada al comienzo y asediada durante dos meses por los milicianos asturianos, había sido socorrida desde Galicia y quedado al extremo de un estrecho corredor que la conectaba con la zona sublevada (Cardona 2006, 111 y 112). Antoniutti explicó que la vetusta ciudad había resistido así durante un año la presión de «sesenta mil hombres y doscientos cañones». La catedral y casi todas las iglesias quedaron "gravemente dañadas", varios edificios educativos destruidos, el seminario inhabitable... Destacó, al respecto, que había sido en el mes de febrero de 1937 cuando el combate contra la ciudad había sido más intenso, señalando que había participado en él un regimiento de soldados católicos vascos que luchaban junto a los «comunistas». Cayeron en la batalla dos capellanes vascos.

Del Santuario de Covadonga informó que se había salvado de la destrucción debido a la rápida intervención de los carlistas en su toma, pero su tesoro había sido en cualquier caso expoliado. En cuanto a Gijón, informó a la Secretaría de Estado que no había sufrido militarmente; tan solo una zona en la que se habían refugiado los «nacionales» al principio de la guerra había sido destruida. Sin embargo, casi todas las iglesias estaban demolidas después de haberlas "expoliado de los tesoros y profanado del modo más sacrílego». En los pueblecitos vecinos que había visitado Antoniutti, los templos habían sido incendiados y los pocos que quedaban estaban dedicados a usos profanos. No había sido posible todavía el cálculo de los edificios que habían sido quemados o demolidos, pero intuía que debía estar en torno al ochenta por ciento.

17 El informe en AES, Spagna (IV), p.o. 916, fasc. 325, ff.62-64, la copia en ASV, Nunziatura di Madrid, b. 969, ff. 480-485. 
En esta ocasión el informe contaba, después de la impresión general, con algunos epígrafes dedicados a determinados aspectos especialmente sensibles de la visita. La ruina moral era el primero de ellos. El encuentro con la zona había producido en el diplomático vaticano una impresión de horror por los crímenes de los «rojos». Hasta el momento había contabilizado en 104 los sacerdotes de la diócesis asesinados, a los que había que añadirle 23 religiosos. ${ }^{18}$ Los supervivientes habían tenido que buscar refugio en otras diócesis o permanecer escondidos con la permanente amenaza de los peores horrores. Arrojaba, además, la cifra de en torno a diez mil "honestos» ciudadanos asesinados en la provincia de Oviedo, dejando como ejemplo de perfidia la supuesta confesión de un miliciano de haber matado por sus medios a 437 personas. ${ }^{19}$ En medio de aquella ruina moral, en la que parecía faltar humanidad a los hombres, Antoniutti se dolía especialmente de las deserciones de dos eclesiásticos, un sacerdote secular y un escolapio. Este último había quemado en público su sotana y se había entregado a "toda suerte de delitos». Caído en manos de los «nacionales», se había convertido y pedido perdón antes de ser "ajusticiado».

Frente a estos motivos de desánimo, Antoniutti también expuso a la Secretaría de Estado aquellos otros de heroísmo, en los que los católicos habían arriesgado su propia vida y puesto a prueba su ingenio para mantener su fe. La misa se había celebrado en casas particulares y la comunión se les había llevado a los fieles de modo oculto. Como ejemplo, el Delegado Apostólico citaba el de una casa gijonesa en que a lo largo de la «dominación roja» se habían consagrado - decía - hasta 43.500 comuniones. Con todo, lo más llamativo era que la situación de persecución hubiera provocado que "en ciertos sectores de la provincia asturiana» se produjesen conversiones y una consolidación de la vida cristiana de diversas familias.

El penúltimo de los epígrafes trataba sobre el clima social de la Asturias que acaba de caer en manos de Franco. Lejos de la sensación de "liberación» que Antoniutti había destacado en Santander, ahora reflejaba la incomodidad de los mineros con el régimen que se les imponía por las armas. Indicaba que, al menos, el cincuenta por ciento de la población asturiana era contrario al «movimiento nacional», aunque añadía que la derrota había sido tremenda y "se sentían todas las consecuencias». Hasta el propio informador entendía que la represión estaba siendo "fuerte»; y mientras que muchos "comunistas» habían huido a las montañas y a los bosques, «los tribunales funcionaban día y noche" y "cuantos eran identificados como reos de homicidios eran pasados por las armas».

18 El número de sacerdotes diocesanos asesinados que aporta Montero Moreno $(2000,764)$ es de 140 . Garralda corrigió el dato, de forma que de 1116 sacerdotes diocesanos consiguió información sobre 1061. De estos, fueron martirizados 129 . En esa cifra incluye a 4 sacerdotes de fuera de la diócesis, 10 asesinados durante la revolución de 1934 y uno asesinado en la primavera de 1934. Los datos se completan con 485 que sufrieron "odiseas», 243 que no sufrieron persecución y 204 que quedaron en zona sublevada (Garralda 1977, 80-81)

19 Lo exagerado de las cifras puede observarse al contrastar con los datos de la investigación más reciente, que, aunque aún provisionales, cifran en torno a 2000 las víctimas de la violencia en Asturias (Ledesma Vera 2010, 247)
En aquella situación, el enviado de Roma se permitía desear para la diócesis un clero tan numeroso como bien formado; a la realidad que contemplaba, por el contrario, no podía asignarle ni uno ni otro adjetivo. En Covadonga, por ejemplo, le había llamado la atención que los capitulares se afanasen antes en recuperar los oficios corales que en la atención pastoral de todas las poblaciones circundantes que estaban no solo sin clero, sino que en muchos casos tampoco podían usar la iglesia. Pero la corona de tantas carencias estaba en la propia cabeza diocesana: vacante la sede metropolitana desde agosto por la muerte en accidente de tráfico del obispo Justo Echeguren, el Vicario Capitular no tenía dotes para el gobierno de aquella grey sometida a tan difíciles circunstancias. Antoniutti decía estar buscando un buen candidato para la diócesis que propondría a Roma en cuanto fuera posible. También había creído oportuno dirigirse a los sacerdotes para fomentar en ellos el celo pastoral y urgirles al acercamiento precisamente a los más alejados, porque esta carencia de religión en muchos entendía que resultaba una de las principales causas de aquel drama.

Finalmente, Antoniutti explicó por sus letras al cardenal Pacelli el uso que había dado al dinero recibido y las principales urgencias económicas de la diócesis, al tiempo que detallaba las obras de caridad que le había permitido llevar a cabo. Cien mil francos que le habían sido remitidos por el presidente de las Conferencias de San Vicente de Paúl de París, de Vergés, los había distribuido para los jóvenes necesitados de la región; de forma que los sacerdotes podrían retomar la catequesis, instruir a los niños y aportarles algunas ayudas materiales. Tanto el clero como las autoridades y el pueblo le habían transmitido el reconocimiento al Papa por la ayuda en aquella hora difícil. Los auxilios materiales también llegaron a las visitas que Antoniutti efectuó en Gijón a un hospital de prisioneros «rojos» y a un instituto para «hijos de comunistas abandonados», donde tuvo para ellos «una palabra de fe, de bondad y de paz».20

Entre los días 19 y 29 de febrero de 1938 el Delegado Apostólico estuvo de nuevo en Gijón para presidir la primera gran manifestación religiosa pública después de «siete años de dominación comunista», es decir, desde el inicio de la República. El principal acto público consistía en el traslado de una imagen de Jesús crucificado que se había salvado "de milagro» del incendio de la iglesia de los jesuitas en 1931 hasta la única iglesia que había quedado en Gijón y que, aunque profanada, no había sido destruida debido a la disposición del caserío. La procesión tuvo un carácter de pública penitencia y dejó una impresión profunda en las calles; incluso en los barrios más populares que en sus letras identificaba como «rojos». La imagen fue llevada hasta las ruinas de tres iglesias parroquiales destruidas con dinamita, después se cantó el «miserere» y el pueblo prometió la reparación del ultraje sacrílego mediante la edificación de nuevas iglesias. ${ }^{21}$

Muchos años después, Antoniutti había de continuar guardando recuerdo de aquella ceremonia de expiación, puesto que en sus memorias dijo de ella que fue uno de

20 El uso del dinero detallado en el informe coincide con el que justificó al final de su estancia en España, al que se alude más adelante.

21 El informe de esta visita a Gijón en ASV, Nunziatura di Madrid, b. 969. ff. 491-493. El original en AES, Spagna (IV), p.o. 915, fasc. 326, ff. $35-36$. 
los «espectáculos más impresionantes». Recordó entonces que la iglesia de San José había sido demolida, la de San Lorenzo incendiada y el resto profanadas. No fue el único episodio que recordó de aquella segunda estancia en Gijón. También le hubo impresionado mucho lo ocurrido al terminar de celebrar la misa en la iglesia de los jesuitas. El monaguillo que le había asistido en la liturgia le confesó que se sentía triste porque ya no podía distribuir la comunión tal y como había hecho antes de la toma de la ciudad. El chico se había ocupado de llevar a los domicilios particulares la eucaristía que había sido consagrada por sacerdotes escondidos en casas de confianza. Recordaba con cierta ternura "haber visto en aquella cálida alma el ansia del sacerdocio» y se ocupó de que fuese acogido en el seminario. Desde entonces, el diplomático vaticano y el chico mantuvieron contacto, siendo ordenado sacerdote en 1950 (Antoniutti 1975, 37).

En su informe a la Santa Sede sobre la segunda visita a la región, Antoniutti destacó la labor que las congregaciones religiosas, y especialmente de los jesuitas, habían venido realizando en cuanto al trabajo pastoral en Gijón desde que estuviese allí a primeros de noviembre de 1937. Gracias, además, a los medios aportados por él mismo y enviados por las Conferencias de San Vicente de Paúl se había iniciado la obra de "reconstrucción religiosa». En concreto, citó la regularización de muchas uniones y el bautizo de centenares de niños, indicando que en muchos barrios populares no se bautizaba a los pequeños desde el inicio de la República. ${ }^{22}$

Pero, junto a la felicitación por las comunidades religiosas, también había motivos para dolerse. Si en el mes de diciembre había narrado el caso de dos sacerdotes «desertores», en esta ocasión eran cuatro los curas detenidos por las nuevas autoridades: uno de ellos había cooperado en el incendio de una iglesia, el segundo había vendido objetos preciosos y vestiduras eclesiásticas, el tercero había ocultado a varios "comunistas» en su casa y el cuarto de ellos había extorsionado a algunos fieles a cambio de su protección ante las nuevas autoridades. Antoniutti había conseguido que fueran trasladados a una residencia de jesuitas, pero utilizaba la situación para urgir a la Secretaría de Estado la toma de posesión del nuevo obispo, Manuel Arce y Ochotorena. ${ }^{23}$

\section{Teruel}

La visita que efectuó a Teruel le llevó a conocer de primera mano la particular situación creada en una ciudad que había sido conquistada por las tropas republicanas y finalmente recobrada por la España de Franco. Se trató de un viaje especialmente comentado por la prensa. Al respecto, en sus memorias, recordaba que un diario de Madrid había efectuado un áspero comentario en el que invitaba

22 Nos deja la duda sobre el carácter voluntario de la recepción de los Sacramentos, dado que al decirse que no los habían recibido desde la llegada de la República no parece claro si mediaba una conversión, una presión o bien un cambio tan solo del ambiente social que hacía conveniente una u otra cosa según las circunstancias.

23 El traslado de Arce y Ochotorena desde a diócesis de Zamora a la de Oviedo había sido dispuesto por la Santa Sede a finales de enero de 1938 (Navarro de la Fuente 2019, 527). al Encargado de Negocios de la Santa Sede a aproximarse un poco más a la línea del frente con la esperanza de que le alcanzaran las armas... Poco antes de la batalla por la ciudad, en noviembre de 1937, Antoniutti se había encontrado con el obispo de la capital turolense, Anselmo Polanco, en Burgos. Este había puesto al corriente al diplomático vaticano de la «incierta» situación de su diócesis y le había manifestado su deseo de volver a su sede para estar junto a su pueblo en el momento de la batalla. Fue allí donde Polanco fue hecho prisionero por las tropas republicanas cuando conquistaron la ciudad (Antoniutti 1975, 38).

El informe dirigido al cardenal Pacelli sobre la visita a Teruel está fechado el 8 de marzo de 1938 y tiene el tono de desolación propio de la contemplación de una ciudad que había sufrido la más encarnizada lucha durante la guerra y en la que tan solo había doce personas en el momento de la "liberación», entre ellas dos religiosas que narraron lo sufrido. La catedral, el seminario y otras tres iglesias habían sido destruidos por los bombardeos y por las explosiones de las minas colocadas por los «rojos» antes de abandonar la ciudad. Dos iglesias que habían permanecido intactas en cuanto a su edificación estaban, sin embargo, profanadas y desprovistas de todo. Como en otros muchos casos, las imágenes habían sido destruidas y mutiladas, de lo que incluso envió a la Santa Sede alguna fotografía. ${ }^{24}$

En cuanto a clero, Antoniutti explicó que en el momento en que monseñor Polanco dejó la ciudad junto con la población civil, el 6 de enero de 1938, estaban refugiados en Teruel 65 sacerdotes y religiosos. De ellos, tan solo uno había podido escapar al territorio «nacional». Según las informaciones del Vicario General de Teruel, confirmadas por las autoridades militares, se había comprobado que 27 sacerdotes, que habían salido hacia la «zona roja» cuando al principio de enero pasó la ciudad a manos republicanas, habían sido finalmente masacrados en el entorno de la capital turolense. A ello había de unirse que, antes de las últimas operaciones militares, 30 sacerdotes habían caído víctimas de los "comunistas». ${ }^{25}$ Del resto de la clerecía no había noticias, confiándose en que pudieran encontrarse entre la población prófuga.

En su huida, las milicias republicanas se habían llevado consigo buena parte del tesoro de la ciudad. Antoniutti confiaba en que en la catedral aún se conservasen las mejores piezas que habían quedado emparedadas, pero cuyas paredes se habían visto afectadas por los destrozos. Por el contrario, el "tesoro de Albarracín» que había estado depositado en el Banco de España parecía estar ahora transferido a Barcelona. El Encargado de Negocios daba detalle de su contenido siguiendo las instrucciones de la Secretaría de Estado por si en algún momento fuera posible su recuperación. Se trataba de veinte cálices, algunos de gran valor, de una colección de tapices, una custodia y una naveta de cristal de roca con perlas. Advertía al respecto que la prensa republicana había publicado que se habían puesto a salvo muchos objetos de valor encontrados en Teruel.

24 Copia del informe en ASV, Nunziatura di Madrid, b. 969, ff. 494-497.

25 Los datos parecen aportados por Antoniutti parecen exceder los 44 sacerdotes asesinados que contabilizó Montero Moreno (2000, 764). 
Al igual que en otras ocasiones, la entrada de las tropas «nacionales» había supuesto la reanudación del culto. También, como en otras regiones, la propia llegada de Antoniutti había generado el entusiasmo de la población que hacía ver al diplomático vaticano que se estaba dando un renacimiento espiritual. En la visita llevó aliento y cierta ayuda económica para algunos sacerdotes, y destinó veinticinco mil pesetas al socorro de los niños huérfanos de la ciudad y su entorno, en el que se incluía también la sufrida diócesis de Huesca. De algunos benefactores había recibido donaciones para cubrir las necesidades más perentorias de algunas iglesias, en las que a no podía celebrarse el culto. Para cubrir cuanto quedaba pendiente pedía de nuevo la ayuda romana. Argumentó su petición en que, durante las visitas había constatado las grandes necesidades de aquella Iglesia. El clero era muy pobre, vivía de lo poco que podía recibir del pueblo y no tenía margen para afrontar las imperiosas necesidades de los edificios de culto que «más que ningunos otros» habían sufrido los horrores de la guerra. Además, por cuanto había constatado, la ayuda prestada en aquellos difíciles momentos no era solo material sino que ejercía una «benéfica influencia moral» en todo tipo de personas.

Antoniutti insistía que la suya había sido una visita solo de carácter religioso y caritativo en una zona «todavía expuesta a los tiros de los enemigos». En el contacto con aquella probada gente, el Delegado recibía una y otra vez síntomas de la preocupación por el cautivo obispo Polanco y señales de la urgencia de su regreso. De él contaban los fieles que se había preocupado con «generosidad verdaderamente heroica» de los asediados por las tropas republicanas antes de caer él mismo prisionero.

Inmerso en el conjunto de visitas a los territorios conquistados, y en plena contienda en Aragón, tuvo lugar la celebración de la Semana Santa de 1938. El Gobierno de Franco decretó festivos el Jueves y el Viernes Santos y participó oficialmente en los sagrados oficios de la Pasión. Con tal motivo, Franco decretó el indulto de 25 condenados a muerte y el Papa se prodigó en las donaciones en metálico para socorrer aquellos territorios. 50.000 pesetas fueron entregadas en nombre del Papa a las diócesis "liberadas», donde «las necesidades eran incalculables». Antoniutti entregó 20.000 pesetas al obispo de Tortosa y 10.000 a cada una de las diócesis de Lérida, Barbastro y Huesca. ${ }^{26}$

\section{Aragón y Castellón}

El 18 de mayo de 1938 se firmó el informe a la Secretaría de Estado sobre la visita que Antoniutti había realizado a los territorios de Aragón y Castellón que habían sido incorporados a la «nueva España» en las semanas anteriores. ${ }^{27}$

26 Copia de la comunicación enviada a Pacelli el 30 de abril de 1938 en ASV, Nunziatura di Madrid, b. 969. ff. 500-503. Se adjuntaba un recorte de prensa en que la Agencia EFE puntualizaba que, con estas últimas donaciones, Antoniutti había repartido más de medio millón de pesetas: 130.000 a Oviedo, 70.000 a Santander, 100.000 al Seminario de Comillas, 25.000 a Teruel, 75.000 a Zaragoza, 25.000 a Huesca, 50.000 a diversos seminarios, 60.000 para la repatriación de niños, 40.000 a Auxilio Social y aquellas últimas 50.000 .

27 La copia del informe en ASV, Nunziatura di Madrid, b. 969, ff. 506-509.
En esta ocasión, el Encargado de Negocios había visitado territorios de las diócesis de Zaragoza, Huesca, Barbastro, Lérida y Tortosa de las que trató en el informe. La visita estaba marcada por la llegada al mar de las tropas de Franco en Vinaroz (Castellón), que habían roto así en dos la zona republicana del Levante, separando Cataluña de la región valenciana. En sus memorias, donde narró su visita a estos territorios con un orden distinto al que refirió en su informe a la Secretaría de Estado, incluyó el relato de la llegada de las tropas franquistas al mar en el Viernes Santo de 1938. Aquel día, "especialmente sagrado en España», los soldados llegaban a la orilla y hacían con el agua el signo de la cruz. Aquella escena le conmovió tanto a él como al propio Pio XI, que regaló un crucifijo a la iglesia del lugar y que se veneró como "Cristo de la Paz» saliendo en procesión cada Viernes Santo (Antoniutti 1975, 39).

El panorama era muy parecido a la devastación que había narrado en otros territorios anteriormente: incendios, destrucciones y profanaciones. Las iglesias habían sido transformadas en depósitos, cines, mercados o garajes. Los casos de Híjar (Teruel) y Morella (Castellón) Ilamaron especialmente la atención de Antoniutti. En el primero de los pueblos el templo fue convertido en un establo con sus correspondientes abrevaderos. En Morella la iglesia pasó a ser un mercado, con sus correspondientes divisiones que dejaron «irreconocible» la nave (Antoniutti 1975, 39).

Sin embargo, aún mayor había sido la impresión que le había causado la profanación de los cementerios donde, entre las abominaciones cometidas por la turba, destacó la obsesiva destrucción de las cruces y cualquier resquicio de símbolo religioso. El informe enviado a la Santa Sede contenía impresiones similares a las que al paso del tiempo recogió en las memorias, donde recordaba la visita a los cementerios de Huesca y Barbastro después de pasar por la ciudad de Zaragoza. El camposanto oscense estaba transformado en un puesto de observación y combate militar por su posición estratégica en el acceso a la ciudad. Los nichos se habían destinado para la acampada de los soldados, por lo que los cadáveres habían sido exhumados e incendiados mientras las imágenes esculpidas en las lápidas fueron cinceladas o rotas a culatazos. Los epitafios de los muertos fueron sustituidos por "macabras e indecentes» inscripciones. Al cementerio de Barbastro fue a rezar ante la tumba del obispo Asensio Barroso, que había sido fusilado en agosto de 1936. Le sorprendió que en el camposanto no quedara ni siquiera una cruz. Las que estaban esculpidas en las lápidas fueron transformadas en signos geométricos de varias formas; incluso las pequeñas cruces que señalaban en cada tumba la fecha de la muerte se convirtieron en estrellas o flores. También habían sido destruidas las iniciales "R.I.P» en todas las lápidas, aunque se habían conservado las homólogas en español D.E.P. cambiándole su significado original. ${ }^{28}$

La profusión de folletos y opúsculos antirreligiosos y "pornográficos» también había irritado a Antoniutti, sorprendido por la «perfidia» de sus autores y propagadores. Frente a ello, como en los casos anteriores, la reanudación del culto en la región había sido inmediata después de la

28 Este aspecto fue recogido tanto en el informe como en las memorias (Antoniutti 1975, 37-38). 
«liberación». Al efecto se habían recuperado las antiguas iglesias cuando era posible y se había usado cualquier otro edificio público cuando no. Sin embargo, la reanudación del culto no era del todo posible por la falta de clero y la penuria de medios para sostener a los curas adecuadamente. En el sur de Aragón, donde la mayoría de la población era de izquierdas y se había pasado a la otra zona, reinaba un "aire de incertidumbre e indiferencia» en el que la gente era "fría y poco practicante». Entendía Antoniutti que ello se debía a la falta de instrucción religiosa previa a la guerra y a la influencia "perniciosa» de la dominación "comunista y atea». En Castellón, sin embargo, la población había retomado la práctica religiosa con fervor y con «visible entusiasmo». Se habían recuperado muchos objetos de culto que habían sido escondidos y custodiados por personas piadosas. En concreto, Antoniutti narró haber visitado, entre otros, los pueblos de Morella, San Mateo, Vinaroz, Benicarló y Peñíscola en la provincia de Castellón y San Carlos de la Rápita en la provincia de Tarragona. En todos ellos había asistido a manifestaciones de fe "vibrantes y nutridas», habiéndose celebrado misiones en algunos de ellos «con grande fruto".

Durante sus visitas, exhortando a la piedad, al perdón y a la paz, Antoniutti había recibido una calurosa acogida popular tanto en Castellón como en Tortosa (Tarragona). Nada al respecto decía de la zona aragonesa. En cualquier caso, quizás el análisis más interesante de aquel periplo lo dé su juicio sobre la actitud del clero: siendo tantas las urgencias pastorales en las zonas conquistadas, la clerecía prefería la seguridad del sostenimiento que otorgaba la atención de las capellanías urbanas de la zona de retaguardia que el celo apostólico que se necesitaba en los territorios que se iban ocupando y donde el clero había sido asesinado, estaba huido o en la miseria. Así, mientras en la basílica del Pilar, en la catedral de Zaragoza y en otras iglesias los sacerdotes se contaban por decenas, en la misma archidiócesis había medio centenar de pueblos que esperaban la llegada de alguno para la celebración de los sacramentos y la atención de las necesidades espirituales. La distribución del clero - concluía - era «una catástrofe». Se había planteado la posibilidad de enviar a los beneficiados dispensados de residencia a las poblaciones sin sacerdotes; pero Antoniutti pedía la intervención de Roma en este sentido porque ni siquiera los obispos se sentían capaces de disponer a su acomodado clero urbano a la misión apostólica en la España rota y mísera de la primera línea. Volvía a repetirse el problema del que ya se había quejado con los capitulares de Covadonga. El Encargado de Negocios insistía, además, en la oportunidad de que el sacerdote estuviese presente en la población en los días inmediatamente posteriores a la toma, y ponía como ejemplo Alcañiz (Teruel), donde algunos fieles le habían pedido el envío de curas para los pueblos de los alrededores, todavía sin asistencia religiosa.

Una vez tomada la diócesis de Tortosa, y acusando como el resto de diócesis devastadas una importante carencia de clero, Antoniutti transmitió al general Jordana, ministro de Exteriores, una súplica del obispo coadjutor de la diócesis, Moll Salord, que actuaba a la vez como administrador apostólico de Lérida:

El Sr. Obispo coadjutor de Tortosa y Administrador Apostólico de Lérida me comunica que ha encontrado en el territorio liberado algunos sacerdotes que por su edad militar deberían incorporarse al ejército. Considerando la extrema penuria de sacerdotes de dicha Diócesis, ruego a V.E. quiera obtener que ellos queden exentos del servicio para atender a las urgentes necesidades espirituales de aquellas Diócesis. - Con esta ocasión me parece oportuno llamar la atención de V.E. para que se tome una medida semejante con todos los sacerdotes de las Diócesis liberadas en adelante que se encuentren en análogas circunstancias. ${ }^{29}$

La información sobre sus viajes por la España de Franco que Antoniutti incluyó en sus memorias se refirió también a algunas otras regiones. De Navarra, que fue el primer territorio al que se había dirigido una vez en España, dijo que era el lugar donde había visto la "fuerza explosiva» de la fe religiosa del pueblo. Los hijos imitaban el ejemplo "heroico» de sus padres y daban a la lucha el carácter místico de una dedicación completa de la que afirmaba que solo podía ser comprendida en aquel ambiente "saturo» de religiosidad. Zaragoza recibió la visita de Antoniutti antes que Huesca. Sus apreciaciones sobre el acomodo del clero en las capellanías y coros no quedaron recogidas en el texto que llevaba a la prensa sus recuerdos; pero sí incluyó referencia al santuario de la Virgen del Pilar. Considerando a la advocación aragonesa patrona de España, el templo que la albergaba era el destino de continuas peregrinaciones que se habían intensificado después de que dos bombas caídas sobre el edificio no hubiesen explotado. ${ }^{30}$ Los artefactos fueron colocados como reliquias (Antoniutti 1975, 37).

Otra de las ciudades a las que dedicó algunas letras en sus memorias fue Toledo. Dijo visitar la capital del Tajo después de su estancia en Teruel y antes de marchar a la costa levantina. Llamaron allí su atención «las cicatrices del legendario asedio» sufrido por el alcázar y la resistencia de sus defensores. De la espiritualidad de éstos destacó que llevasen en procesión hasta la catedral la imagen de la Virgen que les había confortado durante el asedio (Antoniutti 1975, 38 y 39$).^{31}$

\section{LOS SOCORROS DE ROMA}

La visita que Antoniutti efectuó a los territorios que Franco fue incorporando a su dominio mientras el eclesiástico estuvo en España no conllevó solo el reconocimiento del estado de las cosas en ellos y en el oportuno informe a la Santa Sede. Antoniutti procuró los medios para socorrer en lo posible a la Iglesia y a la población de aquellas regiones. Ya el 17 de agosto de 1937 pidió autorización a la Secretaría

29 Copia de la comunicación a Jordana en ASV, Nunziatura di Madrid, b. 968 , f. 413.

30 Las bombas fueron arrojadas por un avión camuflado con la bandera bicolor en la madrugada del 3 de agosto de 1936. En realidad, fueron 3 proyectiles, de los cuales 2 cayeron en el interior del templo y otro en la plaza. Ninguno de ellos explotó. El asunto fue interpretado desde el principio como un milagro de especial protección de la Virgen sobre aquella ciudad de retaguardia (Ramón Solans 2014, 326ss.).

31 El asedio había tenido lugar en los primeros meses de la guerra, resistiendo sus defensores sublevados hasta la llegada de las tropas a finales de septiembre de 1936 (Cardona 2006, 80-81). La gesta fue asumida como uno de los momentos heroicos de la guerra por los vencedores, hasta el punto de que algunos autores han hablado de ella refiriéndola como mitología (Herreros Martín-Maestro 1995). 
de Estado vaticana para comprometerse en la distribución de algunos socorros a la población de Santander, que estaba entonces a punto de ser incorporada al bando autoproclamado nacional. Solicitó al efecto entre 150.000 y 200.000 pesetas que prefería que se le enviasen en libras esterlinas o dólares. ${ }^{32}$ El envío final fue de 300.000 liras italianas que se cursaron a través del arzobispo de Westminster y que resultaron al cambio en 206.050 pesetas. $^{33}$

El 3 de mayo de 1938 Antoniutti elaboró un resumen de cuentas de la gestión que había venido efectuando en los nueves meses que habían transcurrido desde su llegada. Aunque finalmente su permanencia en España se prolongó hasta mediados de junio, esta información económica nos permite completar el conocimiento sobre la actividad de Antoniutti durante su visita a las zonas del territorio que se incorporaban a la España de Franco. En el mes de febrero, con motivo de la celebración del "Día del Papa» y en sustitución del almuerzo solemne que hubiera sido habitual, Antoniutti había destinado 25.000 pesetas para socorrer a los niños de las tres provincias vascas y de Burgos. ${ }^{34} \mathrm{~A}$ los niños de Santander les entregó, a través de su obispo, 50.000 pesetas; y otras 10.000 pesetas más destinó a los orfanatos de la ciudad después de su incorporación a la zona franquista. En el caso de Asturias, entregó al obispo 100.000 pesetas destinadas al socorro de los niños huérfanos y otras 35.000 para los institutos de beneficencia de Oviedo y de Gijón. ${ }^{35}$

El progreso del conflicto en la zona del Ebro dejó otro ámbito de necesidad para los socorros que Antoniutti distribuía. A los institutos de beneficencia de Zaragoza destinó 25.000 pesetas, idéntica cantidad a la que ofreció para los niños abandonados de Teruel. Para los muchachos de Huesca la cifra fue de 20.000 pesetas mientras que a las diócesis de Lérida y de Barbastro destinó 15.000 pesetas a cada una. Las diócesis de León y Urgel recibieron una cantidad menor, contando tanto una como otra con 5.000 pesetas. También esta cifra fue la que destinó a la diócesis de Cartagena. Finalmente, con ocasión de la Pascua de Resurrección de 1938 Antoniutti consignó haber entregado 50.000 pesetas «a los obispos de las diócesis liberadas» para que socorrieran a familias pobres y necesitadas, sin que especificara cuáles fueron las provincias eclesiásticas que se beneficiaron de esta acción.

Todas estas actuaciones completaban las 111.810 pesetas que el enviado de Pio XI señaló haber gastado en la iniciativa del retorno de los niños vascos que había puesto en marcha a su llegada. Sin embargo, no fue la atención a niños, jóvenes y huérfanos la exclusiva destinataria de la caridad del representante del Papa. La puesta a punto de las iglesias para que pudieran volver a su actividad fue otro ámbito de su atención. De esta forma, a la adquisición de enseres

32 La información de 17 de agosto de 1937 en AES, Spagna (IV), p.o. 907 , fasc. 313 , ff. $75-76$.

${ }_{33}$ Carta de agradecimiento de Antoniutti por el envío en ASV, Nunziatura di Madrid, b. 974, f. 11.

34 En el informe sobre la celebración del "Día del Papa», de 14 de febrero de 1937, había indicado que la cifra distribuida había sido 20.000 pesetas, a razón de 5.000 en cada una de las provincias. ASV, Nunziatura di Madrid, b. 969, ff. 18-21.

35 El resumen final de cuentas fechado el 3 de mayo de 1938 en ASV, Nunziatura di Madrid, b. 974, f.1-7. (Navarro de la Fuente 2019, 513-525). y objetos de culto imprescindibles se destinaron 33.494 pesetas mientras que la Santa Sede envió 1.901'40 libras esterlinas para la reparación del Seminario de Comillas y el sostenimiento de algunos de sus seminaristas. ${ }^{36}$

También en relación con la atención a la Iglesia en la zona que pasaba a control de Franco deben situarse los 1.000 dólares que el 12 de abril de 1938 envió el sustituto de la Secretaría de Estado vaticana, Giovanni Battista Montini futuro Pablo VI-, para la aplicación de misas que debían celebrar los sacerdotes huidos de la guerra. Antoniutti guardó 300 para el clero de las diócesis de Solsona, Tortosa y Lérida, igual cantidad para los sacerdotes de Huesca y Barbastro, 200 para Urgel, 100 para el obispo de Cartagena y otro 100 a varios sacerdotes de San Sebastián. A finales de mayo, además, la Santa Sede asumió la compra de dos automóviles para los dos obispos que regían las diócesis de Lérida y Tortosa y de Huesca y Barbastro, por valor de 200 libras esterlinas cada uno. ${ }^{37}$

\section{CONCLUSIONES}

El itinerario que Antoniutti fue siguiendo en su visita a las regiones que pasaron a control de Franco durante su estancia en España le permitió presentar a la Santa Sede una completa visión de la situación en que había quedado la Iglesia en la zona gubernamental y de las diferencias que presentaba este estado en cada una de las regiones. Su recorrido inicial por territorios incorporados a la sublevación donde la Iglesia no había sufrido ataques, pospuso su llegada a las «iglesias devastadas», de las que tuvo primera noticia directa a través del abad de Montserrat. Una vez en el País Vasco se enfrentó, antes que con la destrucción de las iglesias, con el drama de la división política de los católicos del lugar. El enviado pontificio no matizó en sus informaciones la permanencia de los nacionalistas en el orden constitucional, sino que les presentó tanto a ellos como a su clero en coalición con los "comunistas», en clara contraposición a las enseñanzas pontificias. A sus informes a Roma también llevó la acusación de muchos católicos vascos huidos a Santander antes de la caída de Bilbao de haber sido «engañados» por sus curas.

A partir de la toma de Santander, y especialmente de la conquista de Asturias, Antoniutti pudo comprobar los estragos de la persecución a la que había sido sometida la Iglesia en buena parte de la zona gubernamental por las milicias en cuyo poder había quedado la defensa de la República. A los asesinatos de sacerdotes y religiosos había seguido la desaparición del culto y la destrucción de los templos o, cuando menos, su cambio de uso. Fundamentalmente, las informaciones de Antoniutti habían de servir para situar el punto de partida desde el que había de proyectarse la reconstrucción de la Iglesia tanto a nivel humano como material. Al informar de ello, evidenció las diferencias que se apreciaban entre las regiones y dibujó las potencialidades y dificultades de cada una de ellas en orden a su restauración católica, conformando una suerte de "geografía» de la Iglesia que pasaba del lado republicano al franquista de la guerra. En este sentido, a la par que elogiaba el modo en que los

\footnotetext{
36 Navarro de la Fuente 2019, 516.

37 Navarro de la Fuente 2019, 522.
} 
católicos habían conseguido mantener una oculta asistencia religiosa con la distribución de la comunión en Santander y como esta situación había favorecido incluso el retorno a la fe católica de algunas familias tibias o informaba de cómo algunas familias católicas del Levante habían protegido en sus casas importantes piezas del patrimonio religioso local; la situación en Asturias la presentó muy distinta. El elemento minero de la región hizo escribir al representante del Papa que más de la mitad de aquella población era contraria a las nuevas autoridades, que estas estaban siendo muy duras en la represión con tribunales que funcionaban día y noche y continuos fusilamientos. Por todo ello, urgía la toma de posesión del nuevo obispo que orientase a la diócesis en aquella coyuntura y destacaba la necesidad de un clero más numeroso y mejor formado.

En cuanto al clero, en las informaciones de Antoniutti se destacaron los casos de curas que habían traicionado sus votos para unirse a la causa de los enemigos de la Iglesia. Fue el caso de un escolapio que había prendido fuego a su sotana antes de "entregarse a toda suerte de delitos» por los que terminó finalmente siendo "ajusticiado». No fue el único caso que relató Antoniutti. El Delegado Apostólico se detuvo así en un aspecto poco conocido de la respuesta del clero a la guerra, como fue la renuncia a su estado y la adopción de las propuestas de vida de aquellos a quienes la Iglesia tenía como enemigos. Fueron, ciertamente, casos muy contados; pero no dejaron de tener su eco en las informaciones con que la Santa Sede contó sobra la Iglesia de la primera línea del frente en España.

Mucha más trascendencia debió tener la crítica que el enviado apostólico hizo del aburguesamiento del clero. Se refirió a ello, en primer lugar, respecto del Santuario de Covadonga, pero volvió sobre el asunto con ocasión de su visita al Santuario del Pilar y al contraste entre la situación de Zaragoza y la del bajo Aragón. Escandalizó a Antoniutti que el clero local se hubiese dedicado a la recuperación del oficio coral en Covadonga mientras que las poblaciones circundantes no tenían curas que las atendiesen. Circunstancia análoga criticó en los beneficiados de la capital aragonesa, que mantenían sus capellanías mientras las poblaciones de la primera línea no contaban con sacerdote alguno. En este caso, además, en una región con poca disposición a lo religioso y de la que había destacado que muchos de sus habitantes habían huido al otro lado del frente después de la conquista por las tropas franquistas. Antoniutti protestó a Roma por la falta de celo de este clero, pero sobre todo por la incapacidad de los respectivos obispos para imponerles el destino que juzgaban más pastoralmente necesario.

Un aspecto particularmente llamativo sobre lo religioso en el tránsito de una zona a otra de la España de la Guerra Civil estuvo en la actitud que el clero había de sostener durante los primeros momentos de la nueva situación. Contamos al respecto con las orientaciones que Eguino y Trecu dirigió a su clero para la diócesis montañesa, pero también Antoniutti se refirió a las prioridades que debían atender los sacerdotes a su llegada a las parroquias que se restauraban en la zona franquista. El obispo había pedido prudencia a sus sacerdotes para que no llegasen al pueblo de la mano de las tropas y se viesen inmersos en los fusilamientos que se siguieran. En aquellos primeros momentos la asistencia religiosa debían ofrecerla los capellanes castrenses. De esta forma se evitaba que la población vinculase al sacerdote que había de atenderles con regularidad con la represión sumaria de los primeros momentos de la conquista. Sin embargo, ni Eguino y Trecu en sus orientaciones ni Antoniutti en sus opiniones dejaron de señalar la conveniencia de que el clero se incorporara a la vida de cada una de las poblaciones a la mayor brevedad para garantizar la restauración de la vida católica en ellas. Al respecto consideraron fundamental proceder al bautizo de los niños que no hubieran recibido la iniciación cristiana y regularizar la situación de los matrimonios civiles y concubinatos que hubiera. En este último caso Eguino y Trecu, que escribió sus orientaciones antes de que el Gobierno de Franco hubiese legislado al respecto, pidió que se solicitasen al Vicario General las indicaciones pertinentes para cada situación, sin acudir a medidas de carácter general. En muchos casos, a la incorporación de las poblaciones al dominio franquista siguió la celebración de misiones populares para favorecer esta restauración católica.

Como se ha señalado, la información a partir de lo observado en las visitas no fue la única finalidad que tuvieron las estancias de Antoniutti en los territorios recién incorporados al dominio de Franco. El representante del Papa se afanó igualmente en la atención con donativos de la población que había sufrido la guerra. En este sentido, las cuentas presentadas por Antoniutti casi al final de su gestión dan fe de las cantidades que distribuyó en las regiones afectadas. Desde su visita a Santander, el diplomático vaticano solicitó el envío de fondos por parte de la Santa Sede para atender las necesidades más urgentes de la Iglesia y la población de aquellos lugares. Esta actitud de apoyo económico se mantuvo durante toda su misión en las distintas regiones, aunque con desigual profundidad. En sus informaciones a la Secretaría de Estado vaticana sobre la entrega de estas dádivas, Antoniutti destacó su «benéfica» influencia espiritual, de forma que cabía entender que las atenciones materiales disponían mejor hacia la Iglesia a los receptores. A ellas se debe, en gran medida, el recuerdo que la prensa y muchos de los coetáneos tuvieron de la «caridad» de monseñor Antoniutti. Una caridad que no fue solo iniciativa personal - aunque también parece que algunas aportaciones debieron ser suyas - sino que se dedicó a distribuir los recursos enviados por la Santa Sede y otras obras católicas como las Conferencias de San Vicente de Paúl de muchas partes del mundo. Estas atenciones a los «territorios liberados» supusieron una cuantía bastante superior a la destinada a la obra de retorno de los niños vascos que no fue, en modo alguno, la única iniciativa caritativa de la Santa Sede durante la Guerra Civil. Por el contrario, la Iglesia se preocupó de la restauración de sus estructuras perdidas durante la guerra y se afanó, especialmente, en la restauración del culto y en la preparación de los nuevos sacerdotes. No en vano, las atenciones a la «iglesias devastadas» tuvieron su complemento en la restauración del Seminario de Comillas para la formación de los seminaristas.

\section{BiBLIOGRAFÍA}

Albareda, Anselm. 1972. Historia de Montserrat. Barcelona: Publicaciones de la Abadía de Montserrat.

Alonso Carballés, Jesús Javier. 1998. 1937, los niños vascos evacuados a Francia y Bélgica. Historia y memoria de un éxodo infantil, 19361940. Bilbao: Asociación de niños evacuados el 37. 
Antoniutti, Ildebrando. 1975. Memorie autobiografiche. Udine: Art Grafiche Friulane.

Botti, Alfonso. 2007. "La Iglesia vasca dividida. Cuestión religiosa y nacionalismo a la luz de la nueva documentación vaticana». Historia Contemporánea 35: 451-489.

Cárcel Ortí, Vicente. 2008. Pío XI entre la República y Franco: angustia del Papa ante la tragedia española. Madrid: Biblioteca de Autores Cristianos.

Cardona, Gabriel. 2006. Historia militar de una guerra civil. Estrategias y tácticas de la guerra de España. Barcelona: Flor del viento ediciones.

Dionisio Vivas, Miguel Ángel. 2015. Por Dios y la Patria. El cardena Gomá y la construcción de la España Nacional. Toledo: Instituto Teológico San Ildefonso.

Garralda García, Ángel. 1977. La persecución religiosa del clero en Asturias (I. Martirios), 1934 y 1936-37. Avilés: Gráficas Summa.

Herreros Martín-Maestro, Isabelo. 1995. Mitología de la Cruzada de Franco. El Alcázar de Toledo. Madrid: Ediciones Vosa.

Irazabal Agirre, Jon. 2001. 1937 martxoak 31 - Durango 31 De Marzo De 1937. Vizcaya: Gerediaga Elkartea.

Ledesma Vera, José Luis. 2010. «Una retaguardia al rojo. Las violencias en la zona republicana». En Violencia roja y azul. España, 1936-1950, coord. Francisco Espinosa Maestre, 149-247. Barcelona: Crítica.

Martínez Sánchez, Santiago. 2007. «Mons. Antoniutti y el clero nacionalista vasco (julio-octubre de 1937)». Sancho el Sabio 27: 39-79.
Montero Moreno, Antonio. 2000. Historia de la persecución religiosa en España (1936-1939). Madrid: Biblioteca de Autores Cristianos.

Navarro de la Fuente, Santiago. 2018. «Religión y nacionalismo en la Congregación de la Pasión durante la Guerra Civil (agosto de 1937-enero de 1938)». En De la Historia Eclesiástica a la Historia Religiosa. Estudios en homenaje al profesor Feliciano Montero García, 393-408. Alcalá de Henares: Servicio de Publicaciones de la Universidad de Alcalá.

Navarro de la Fuente, Santiago. 2019. La Santa Sede y la Guerra Civil. Los representantes del Papa en la España en conflicto (1936-1938). Sevilla: Editorial de la Universidad de Sevilla.

Pablo Contreras, Santiago de, Joseba Goñi Galarraga y Virginia López de Maturana. 2013. La diócesis de Vitoria: 150 años de historia (1862-2012). Vitoria: Eset - Obispado de Vitoria.

Pazos, Antón M. 2013. "La Santa Sede, la República y los niños vascos: una batalla diplomática dentro de la guerra civil española». Hispania Sacra 131: 385-423. https://doi.org/10.3989/ hs.2013.012

Ramón Solans, Francisco Javier. 2014. La Virgen del Pilar dice... Usos políticos y nacionales de un culto mariano en la España contemporánea. Zaragoza: Prensas de la Universidad de Zaragoza.

Robles Muñoz, Cristobal. 2009. "En favor de las víctimas de la guerra». Hispania Sacra 124: 691-753. https://doi.org/10.3989/hs.2009. v61.i124.102 